\title{
ACTIVITIES OF THE NATIONAL RED CROSS AND RED CRESCENT SOCIETIES
}

\author{
The Libyan Red Crescent \\ Training and Study Centre
}

The Libyan Red Crescent Training and Study Centre was founded in April 1984 by a decision of the Third General Assembly of the Libyan Red Crescent.

\section{Aims and structure}

The aims of the Centre are to prepare and publish research papers about Libyan Red Crescent health and social activities and to organize symposia, seminars and training courses for active staff from headquarters and local branches of the Libyan Red Crescent in various aspects of humanitarian work. It co-ordinates and participates in the dissemination of the fundamental principles of the International Red Cross and Red Crescent Movement and international humanitarian law.

The Centre may also be consulted on legal and technical matters and can set up ad hoc committees to study plans and programmes for Red Crescent activities. It awards prizes and grants to encourage research, and produces audiovisual material.

The Centre has a Standing Commission made up of six people, four of whom are appointed to four-year terms by the General Assembly. The Director and the delegate from the General Secretariat are appointed by the Secretary General himself. The Commission members decide on general policy for the activities of the Centre and approve the annual budget. They draw up programmes for symposia, training courses and national and international seminars. The Director, Mr. Mohammad Hamad Al Asbali, makes suggestions for activities and represents the Centre in contacts with similar Red Cross and Red Crescent organizations. 


\section{The Centre's training activities}

The Centre's achievements in the field of training include:

- two national training courses organized from 14-18 October 1984 and from 23-29 September 1985 for relief officers from branches of the Libyan Red Crescent. The first course was attended by 38 representatives from 10 branches, the second by 30 representatives, also from 10 branches;

- a first-aid course for medical and dentistry students from the Faculty of Medicine (1-24 March 1986);

a national training course for first-aid instructors, from 2-10 February 1988, attended by 31 delegates from 30 branches;

- the first national course on the dissemination of the Principles of the Red Cross and Red Crescent and international humanitarian law, held from (1-4 December 1984 and attended by 35 representatives from 10 branches;

- the first national course on accounting and financial management (2730 September 1986) which aimed to define and standardize the accounting and financial procedures used by branches of the Libyan Red Crescent;

- the first national course for information officers (21 March-4 April 1987) to develop and improve their abilities in various areas of Red Crescent activity. The course was attended by 27 representatives from 22 branches.

Among the Centre's activities between 1988 and 1990, special mention should be made of a Seminar on Voluntary Service in Social Work, which was held from 20-23 March 1989. The seminar's purpose was to evaluate the experience gained with volunteers of the Libyan Red Crescent and other Libyan volunteer organizations, to draw the necessary conclusions for the future development of social welfare activities and to ensure co-ordination between the agencies concerned.

The seminar was attended by representatives of the Libyan Red Crescent and about 60 delegates from the following institutions: the Libyan Scouts Congress, the Benghazi Association for the Blind, the Centre for Scientific Research, the Libyan Women's Association and several social and cultural organizations. University professors, in particular from Garyounis University, participated and the ICRC was also represented.

Some of the topics dealt with were the nature of voluntary service, volunteer work in Libyan customs and traditions, the recruitment and training of volunteers, several aspects of volunteer social work in the face of social and cultural changes, and the co-ordination of volunteer work by national volunteer institutions. 
The delegates adopted conclusions and made recommendations: while reasserting their deep respect for the religious precepts on which volunteer service is based, they nevertheless said they were anxious to adapt such service to the realities of the modern world, and consequently to set up structures and methods, in particular the development of continuous training programmes for volunteers, so as to give fresh impetus to voluntary service in Libya. The points emphasized included the value of initiative, the effectiveness of collective work and the need to draw up rules on the rights and duties of volunteers and to make the public aware of the concept of voluntary service.

The Centre has planned a further series of courses, to train delegates for tracing activities, on rescue operations and medical aid in the event of a natural disaster, on the dissemination of international humanitarian law (definition of the material to be disseminated, identification of target groups, means and methods of dissemination, etc.) and on disaster preparedness (preparing relief supplies beforehand, defining the role of the national institutions concerned and co-ordinating their activities, and examining the feasibility of devising a national disaster relief plan).

\section{Study and research}

The Centre meets requests for advice, study projects and research addressed to it by local committees and other specialized bodies of the Libyan Red Crescent. In particular, it gives legal and technical advice on administration, management and social work.

Among the studies carried out by the Centre are an assessment of the programmes of activity of the Libyan Red Crescent and its branches, a survey of blood donors and a feasibility study for a health centre near the phosphorous springs in the Udane region. It has also compiled an index of medical services and issued several publications for young people or for use in dissemination programmes. 